\title{
LETTERS
}

\section{An opportunity for pharmacists and physicians to collaborate to prevent violence}

Barbara Sibbald's article highlights important deficiencies in our understanding of the effectiveness and appropriateness of interventions for workplace violence. ${ }^{1}$ Sibbald points out circumstances through which, "violence becomes part of the job." The research in this area is limited for community pharmacists ${ }^{2}$ and pharmacy students $^{3}$ but many experience verbal abuse as "part of the job." A survey sample of Australian community pharmacists $(n=248)$ revealed that about one-third had experienced verbal abuse monthly and $15 \%$ had experienced it weekly. ${ }^{2}$ Bullying and intimidation was reported as occurring once per month by $15.7 \%$ of community pharmacists and robberies were reported by $6.5 \%$. The impact of violence was also substantial, with $19 \%$ reporting reluctance to return to work and more than half reporting that they returned from work feeling anxious, angry, depressed or irritable. ${ }^{2}$

The rise in opioid use and related harms experienced by Canadians over the past 10 to 20 years has been well documented and extensively discussed. ${ }^{4,5}$ Pharmacists are inextricably linked to prescribers (i.e., phy- sicians and nurse practitioners) because of their role as stewards of the medication supply, including controlled drugs and substances. Clinical circumstances (e.g., patient safety) and regulatory considerations (e.g., rules surrounding quantities, part-fills and refills) can result in the pharmacist appearing to act in conflict with the patient's or the prescriber's (or both) intentions. We have found that substantial tensions can exist among patients, physicians and pharmacists within this complex phenomenon of opioid treatment and that issues such as verbal abuse, bullying and intimidation may arise. ${ }^{6}$

Although forms of violence (e.g., robbery $^{7,8}$ ) toward pharmacists in retail environments may differ from those experienced by other health care professionals, shared similarities with practice characteristics and roles (e.g., working as sole practitioners or with few staff) may allow for the development of interventions that are transferrable among groups and settings. The opioid crisis presents us with an opportunity to more comprehensively understand violence and look at shared solutions in prevention.

\section{Andrea L. Murphy BSc PharmD}

Associate Professor, College of Pharmacy, Dalhousie University, Halifax, NS
Cite as: CMAJ 2017 May 1;189:E644. doi: 10.1503/cmaj.732952

\section{References}

1. Sibbald B. Workplace violence is not part of a doctor's job. CMAJ 2017;189:E184.

2. Peterson GM, Tan SI, Jackson SL, et al. Violence in community pharmacy in Australia: incidence and implications. Int J Clin Pharm 2011;33:264-72.

3. Rahim H, Shah B. Pharmacy students' perceptions and emotional responses to aggressive incidents in pharmacy practice. Am J Pharm Educ 2010;74:61.

4. Dhalla IA, Persaud N, Juurlink DN. Facing up to the prescription opioid crisis. BMJ 2011;343:d5142.

5. Prescription drugs. Ottawa: Canadian Centre on Substance Abuse. Available: www.ccsa.ca/Eng/topics /Prescription-Drugs/Pages/default.aspx (accessed 2017 Feb. 28).

6. Murphy AL, Phelan $\mathrm{H}$, Haslam S, et al. Community pharmacists' experiences in mental illness and addictions care: a qualitative study. Subst Abuse Treat Prev Policy 2016;11:6.

7. The Canadian Press. 2 men wearing disguises allegedly rob 6 Toronto pharmacies over 2 weeks. $C B C$ News 2017 Jan. 19. Available: www.cbc.ca/news/ canada/toronto/2-men-wearing-disguises-allegedly -rob-6-toronto-pharmacies-over-2-weeks-1.3943856 (accessed 2017 Feb. 28).

8. Woo A. All B.C. pharmacies must now store drugs in time-delay safes. Globe and Mail [Toronto]. Available: www.theglobeandmail.com/news/british -columbia/all-bc-pharmacies-must-now-store-drugs -in-time-delay-safes/article26375550/ (accessed 2017 Feb. 28).

Competing interests: None declared. 